\title{
Traumatic reticuloperitonitis in cattle: A clinical study
}

\author{
B. Sudhakara Reddy*, L.S.S.Varaprasad Reddy, S. Sivajothi and B. Somasekhara Reddy \\ Teaching Veterinary Clinical Complex, \\ College of Veterinary Science, Sri Venkateswara Veterinary University, \\ Proddatur - 516360, Y.S.R.District, Andhra Pradesh, India \\ *Corresponding author E-mail: bhavanamvet@gmail.com
}

Copyright () 2014 B.Sudhakara Reddy et al. This is an open access article distributed under the Creative Commons Attribution License, which permits unrestricted use, distribution, and reproduction in any medium, provided the original work is properly cited.

\begin{abstract}
A cow with history of fever, anorexia, sudden milk drop and stiff gait was referred to the Teaching Veterinary Clinical Complex, College of Veterinary Science; Proddatur. Examination of the cow revealed fever, tachycardia, tachypnoea, with ruminal atony associated with mild bloat and dehydration was noticed. The cow exhibited light pain while palpation at brisket region. Hot and pain full edema was noticed at brisket region and at ventral abdomen. Animal exhibited positive response to metal detector. Haematology revealed significant erythrocytopenia, higher PCV, lower haemoglobin concentration, significant leucocytosis with neutrophilia, presence of more number of immature neutrophils and decreased lymphocyte count. Sero biochemical findings had reduced glucose, sodium, potassium, chloride, calcium, phosphorus levels and increased levels of total protein, globulin, AST, ALT, creatinine was noticed. Cow was treated with Inj. strepto penicillin, Inj.neoprofen along with supportive therapy.
\end{abstract}

Keywords: Traumatic Reticuloperitonitis, Signs, Laboratory Findings, Cattle.

\section{Introduction}

Traumatic reticuloperitonitis, also known as hardware disease is relatively common diseases in adult cattle caused by the ingestion of foreign bodies. Among the numerous diseases of foreign body syndrome in ruminant species, traumatic reticuloperitonitis (TRP) and traumatic pericarditis (TP) are the most common. TRP is a sporadic disease in ruminants caused by perforation of the reticulum due to ingestion of foreign materials. Cattle are more susceptible to foreign body syndrome than small ruminants because they do not use their lips for prehension and are more likely to eat chopped feed [1]. Lack of oral discrimination in cattle may lead to ingestion of foreign bodies that would be rejected by other species. Moreover, the honeycomb-like structure of the reticulum provides many sites for fixation of a foreign body, and contractions of the reticulum may be sufficient to push a sharp foreign body through the wall, inducing the disease. Development of severe sequelae to the penetration of the reticular wall depends on the characteristics of the foreign body as well as the direction and the extents of the penetration [2]. Present paper describes the clinical and laboratory findings of cattle with traumatic reticuloperitonitis.

\section{Case history and observations}

An eight years old crossbred cattle was referred to the Teaching Veterinary Clinical Complex, College of Veterinary Science; Proddatur with a history of fever, anorexia and progressive weight loss with difficulty while walking. The cow was treated for pyrexia at local dispensaries from the last ten days. The cow was regularly feed with chaffed feed, paddy straw and allowed for grazing at surroundings of waste dumping area in the village. Physical and clinical examination of the cow revealed fever $\left(104.6^{\circ} \mathrm{F}\right)$, tachycardia $(86 / \mathrm{min})$, tachypnoea $(38 / \mathrm{min})$ congested congunctival mucus membranes, severe dehydration, mild ruminal atony associated with bloat. Hot and pain full edema was noticed at ventral aspect of abdomen and brisket region (Figure-1). Pain tests were conducted according to the methods of Rosenberger [3]. Whole blood was collected in EDTA containing vial for routine haematology. Serum was separated for estimation of sero bio-chemical parameters. Peripheral blood smear was collected for screening of haemoprotozonas 
and dung sample was collected to screen for endo-parasitic infections. Peritoneal fluid and ruminal fluid was also collected for laboratory analysis.

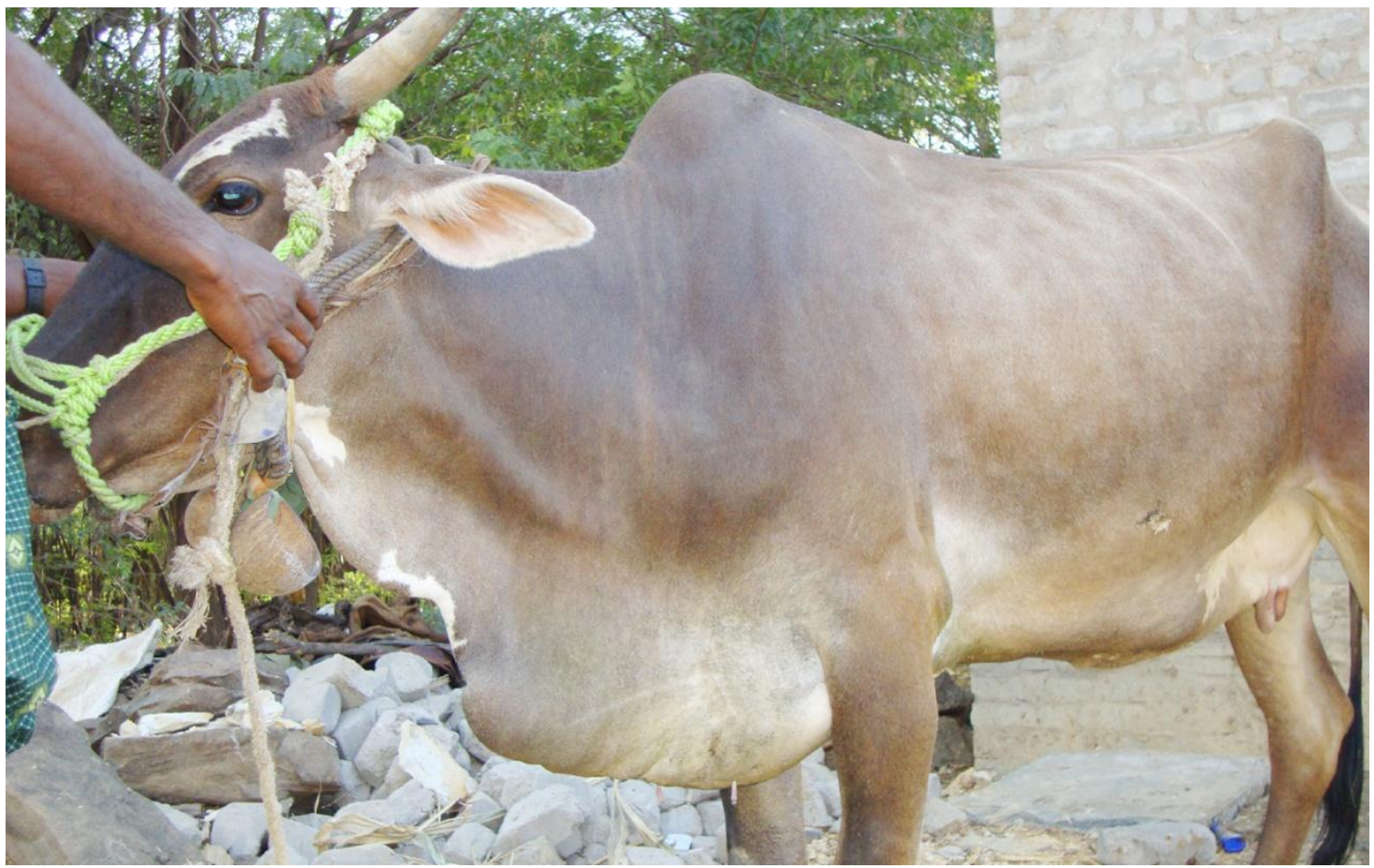

Fig. 1: Cattle with traumatic reticulo peritonitis.

\section{Results and discussion}

Examination of the cow revealed pain while back grip test and palpation for tenderness. Cow exhibited pain while palpation at brisket region and positive response while examination with metal detector at reticular region. Peripheral blood examination and stained smears did not reveal any haemoprotozoans. Haematology had significant erythrocytopenia $(4.95 \times 106 / \mu \mathrm{L})$ with lower haemoglobin $(7.9 \mathrm{~g} / \mathrm{dL})$ concentrations and higher PCV $(39 \%)$, significant leucocytosis $(14,943 / \mu \mathrm{L})$, neutrophilia $(11,887 / \mu \mathrm{L})$, presence of more number of immature neutrophils $(72 \%)($ Band cells) than mature neutrophils and decreased lymphocyte count $(2,578 / \mu \mathrm{L})$, normal monocyte count $(152 / \mu \mathrm{L})$, eosinophil count $(326 / \mu \mathrm{L})$ was noticed. Sero biochemical parameters had reduction in glucose (44 mg/dL), sodium (121 $\mathrm{mEq} / \mathrm{L})$, potassium $(2.8 \mathrm{mEq} / \mathrm{L})$, chloride $(72 \mathrm{mEq} / \mathrm{L})$, and calcium $(7.8 \mathrm{mg} / \mathrm{dL})$, phosphorus $(4.1 \mathrm{mg} / \mathrm{dL}) \mathrm{levels}$. Elevated levels of total protein $(12.2 \mathrm{mg} / \mathrm{dL}$, globulin $(8.6 \mathrm{mg} / \mathrm{dL})$, AST $(82 \mathrm{IU} / \mathrm{L})$, ALT (42 IU/L), creatinine $(2.1$ $\mathrm{mg} / \mathrm{dL})$ was noticed. Minor deviations were noticed in BUN (28 mg/dL) and serum albumin (3.6 mg/dL) levels. Rumen liquor was collected from left paralumbar fossa through a sterile $16 \mathrm{G}$ needle. Ruminal fluid was viscous in consistency, pH was 7.0 and protozoal concentration was 'single +' with sluggish motility. Peritoneal fluid was collected which was in dark straw colored, cloudy and foamy in nature. It contains higher number of nucleated cells, immature and degenerative neutrophils. Peritoneal fluid had higher protein $4.1 \mathrm{~g} / \mathrm{dL}$ levels.

Based on the history, clinical and laboratory examination of peritoneal fluid along with positive response to metal detector condition was diagnosed as traumatic reticuloperitonitis. The cow was treated with injections of strepto penicillin@15,000 IU/kg body weight BID I/M, Inj.neoprofen @ 2 mg kg body weight IM, chlorphenaramine maleate @ $0.5 \mathrm{mg}$ kg body weight IM. Multivitamins injection @ $10 \mathrm{ml}$ per day and Inj.Frusemide @ 2 mg kg body weight IM for one week period. Additionally Ecotas boli (Probiotics) one BID PO was advised for one more week. Post treatment clinical examination revealed reduction in the size of brisket edema. Hematological examination revealed normal DLC along with improvement in hemoglobin levels. In spite of the present therapy cow was died after 12 days of post therapy.

Based on clinical findings of this study, intermittent anorexia, chronic bloat, weight loss, decreased milk production and rumen dysfunction were best indexes for chronic local peritonitis. In the present study, the cow affected with traumatic reticuloperitonitis developing diffuse peritonitis resulting had fever, elevated heart rates, elevated respiratory rates, cessation of milk flow and appetite which is in agreement with the findings of previous studies [4]. Elevated rectal temperature in this case indicative of systemic reaction, increase in the respiratory rate indicates respiratory distress associated with toxemia and septicemia caused by the foreign body penetration. Ruminal movements were markedly depressed indicating significant hypomotility of the rumen. All these clinical abnormalities were similar to previous studies [5]. 
The observed decrease in total erythrocyte count and hemoglobin concentration indicates anemia, which could be attributed to the loss of blood during penetration of the reticulum or the chronic inflammatory process [6]. Increased in hematocrit values could be attributed to dehydration associated with fluid loss due to the reduction of food and water intake [7]. Increase in total leukocytic count with neutrophilia was noted in this case was in agreement with Aref NM \& Abdel-Hakien MAH [8], it mainly because of inflammatory responses due to infection associated with the penetration of the reticulum and diaphragm [9 and 10]. Serum electrolyte analysis showed significant reductions in the levels of sodium, potassium, and chloride in this cow it may be due to ruminal hypomotility and/or vagal indigestion. Hypochloremic metabolic alkalosis may occur due to sequestration of hydrochloric acid in the rumen caused by rumen stasis or vagal indigestion. Hypokalemia is caused primarily by anorexia, but may be potentiated slightly by ion exchange caused by the alkalosis and/or abomasal reflux into the rumen. With alkalosis, intracellular H+ ions can be exchanged for extracellular $\mathrm{K}+$ ions, decreasing serum potassium concentrations. This effect is minor compared to the $\mathrm{K}+$ ion shifts associated with acidosis [9]. Hypocalcemia can occur due to reduced calcium uptake as a result of illnesses that affect the appetite and decrease its absorption. In the present case it may be due to gastrointestinal stasis and insufficient dietary uptake. The levels of blood urea nitrogen and creatinine were significantly higher, which might have been due to renal insufficiency that resulted from dehydration and a reduction of renal blood flow with subsequent prerenal azotaemia. The observed reduction in the glucose level might have been due to the anorexia observed in the cows with TP and subsequent starvation $[11,12]$. In a study of cattle suspected of having TRP that also had a total plasma protein concentration of $100 \mathrm{~g} / \mathrm{L}(10 \mathrm{mg} / \mathrm{dL})$ had an $83 \%$ chance of having TRP, $83 \%$ of the cattle with a total plasma protein concentration of $10 \mathrm{mg} / \mathrm{dL}$ had TRP [13].

\section{Conclusion}

In the present study, complete clinical and laboratory findings were recorded pertaining to traumatic reticulo peritonitis in cattle.

\section{Acknowledgements}

The authors are thankful to Dr.G.S.Reddy, Veterinary Assistant Surgeon, Veterinary Poly Clinic, Kadapa for providing the metal detector during this study. First author expressed his special thanks to S. Jagadeeswar Reddy (B.Sc. Bitch., MBA) for his cooperation while analysing of clinical samples.

\section{References}

[1] U. Braun, Ultrasonography in gastrointestinal disease in cattle, Veterinary Journal, 2003, 166: 112-124.

[2] H.I. Gokce, G. Gokce, M. Cihan, Alterations in coagulations profiles and biochemical and hematological parameters in cattle with traumatic reticuloperitonitis, Veterinary Research Communication, 2007, 31: 529-536.

[3] G. Rosenberger, Clinical Examination of Cattle. 1st edn. Verlag Paul Parey, Berlin and Hamburg, 1979.

[4] S. Hajighahramani and M.Ghane, Traumatic reticuloperitonitis in cattle of Khorramabad (Center of Lorestan Provenience, West of Iran). Global Veterinaria, 2010, 5(2): 135-139.

[5] O.M. Radostits, C.C. Gay, K.W. Hinchcliff, P.D. Constable, Traumatic reticuloperitonitis In: Radostits, O.M., Gay, C.C., Hinchcliff, K.W., Constable, P.D. Eds., Veterinary Medicine: A Textbook of the Diseases of Cattle, Horses, Sheep, Pigs and Goats. 10th edn. Elsevier Health Sciences, Philadelphia, PA, USA, 2007; 337-352.

[6] N. Ocal, G. Gokce, A.I. Gucu, E. Uzlu, B.B. Yagci, K. Ural, Pica as a predisposing factor for traumatic reticuloperitonitis in dairy cattle: serum mineral concentrations and hematological findings. Journal of Animal and Veterinary Advances, 2008, 7, 651-656.

[7] G. Rosenberger, Clinical Examination of Cattle. 1st edn. Verlag Paul Parey, Berlin and Hamburg, 1979.

[8] N.M. Aref and M.A.H. Abdul-Hakiem, Clinical and diagnostic methods for evaluation of sharp foreign body syndrome in buffaloes, Veterinary World, 6(9), 2013, 586-591.

[9] K.S. Latimer, E.A. Mahaffey, K.W, Prasse, Duncan and Prasse's Veterinary Laboratory Medicine: Clinical Pathology, 4th edn., Ames, Iowa State Press, 2003, 68-77, 152-160.

[10] U. Braun, M. Gotz, O. Marmier, Ultrasonographic findings in cows with traumatic reticuloperitonitis, Veterinary Record, 1993 , 133 , 416-422.

[11] A.J. Roussel, M.S. Whitney, D. Cole, Interpreting a bovine serum chemistry profile: Part 1. Vet. Med., 1997; 92: 551-558.

[12] A. Samad, K.B. Awaz, L.B. Sarkate, Diagnosis of bovine traumatic peritonitis. I: strength of clinical signs in predicting correct diagnosis. $J$. Appl. Anim. Res., 1994, 6: 13-18.

[13] R.A. Dubensky and M.E. White, The sensitivity, specificity, and predictive value of total plasma protein in the diagnosis of traumatic reticuloperitonitis. Can J Comp Med, 1983, 47:241-244. 